\title{
ENHANCING STUDENTS’ WRITING SKILL THROUGH BLOGGING
}

\author{
${ }^{1}$ Luthfiyah Apriani \\ ${ }_{2}$ Melati \\ ${ }^{1}$ Post Graduate Student of English Education Program, Bengkulu University \\ luthfiyah.apriani@yahoo.com \\ ${ }^{2}$ Lecturer of Faculty of Teacher Training and Education of UNIHAZ Bengkulu \\ melati@unihaz.ac.id
}

Received on April, 14th, Revised on June, 29th, Published on July, 30th 2018

\begin{abstract}
Nowadays, people are expected to be able to write and literate. As one of the important skills in language learning, writing has been considered as an important role in all aspects of life. In order to help our students having a good skill in writing, the use of technology is chosen to be integrated in the learning process. And Blogging is one of the activity that can be used to motivate the students to write actively and constructively. By using blog, teachers can help students to write constructively, promote student's autonomy and enhance their motivation.
\end{abstract}

Keywords: Lecturers, Questions, Response, Students.

\begin{abstract}
ABSTRAK
Saat ini, setiap orang diharapkan dapat menulis dan membaca. Sebagai salah satu keterampilan penting dalam pembelajaran bahasa, kemampuan menulis telah dianggap sebagai peran penting dalam semua aspek kehidupan. Untuk membantu siswa kami memiliki keterampilan menulis yang baik, penggunaan teknologi dipilih untuk diintegrasikan dalam proses pembelajaran. Dan Blogging adalah salah satu siswa untuk menulis secara aktif dan konstruktif. Dengan menggunakan blog, guru dapat membantu siswa untuk menulis secara konstruktif, meningkatkan otonomi siswa dan meningkatkan motivasi mereka.
\end{abstract}

Kata Kunci: Dosen, Pertanyaan, Tanggapan, Siswa. 


\section{INTRODUCTION}

Writing is one of the basic skill that should be had by the students in the teaching and learning process. Nowadays, people are expected to be able to literate. These activities are considered an important role in all aspects of life. People can get information from reading then share with the others through writing. Moreover, writing can be a good facilitator for us to express everything. Writing is the activity of using brain and hand at the same time to express about what we are thinking into words. According to Harmer (2001:79), "Writing is a form of communication to deliver thought or to express feeling through written form." In addition Saleh (2015) stated that the skills in writing cover the ability to write correct sentences, the ability to manipulate sentence, and use language effectively, ability to use punctuation and spelling correctly, and the ability to write in an appropriate manner for the particular purpose with a particular audience in mind together with an ability to select and organize relevant information.

In fact, writing is an activity that is used as one of the tools of communication in human life. It can be a good way to communicate with others. People can share or express everything freely without thinking of shy as we did in the direct communication. But, in fact, sometimes writing is not an easy way to use. This ability will not come by itself. It is obtained through learning. In relation to this case, students sometimes also still feel reluctant to write. There're some factors that affect it. Such as lack of vocabularies, does not have enough knowledge about what to write nor how to write sentence and paragraph well, or it can be also because they have learned about the grammatical structures. So that, they feel afraid of making mistakes in writing activity. Moreover, Santoso (2016) said that the students when learning English writing, are not motivated to write. They tend to be more interested in knowing the technique of writing rather than moving their hands to write in English. Therefore, as a teacher, it will be our responsibility to find out an appropriate strategy or technique that can be used in our teaching and learning process to enhance our students' writing skill. As stated by Dunlosky, Marsh, Nathan \& Willingham (2013), one part of the situation to help students to get a better regulation in their learning is through the use of effective learning techniques.

In this modern era where everything can be got or done by technology, students have been more interested in using technology. As a teacher, we should be more flexible, innovative, and creative. We can use the facility from technology to help us in teaching and learning process. As Amiri (2012) said that "The use of technology in 
various fields has been so successful and beneficial for teachers to reach some particular goals especially in education and for those who are learning a foreign language and literature." In relation to writing skill, one of the facilities that can be used is a blog. Today, web technologies including blogs are presenting both teachers and students with new horizons in the field of teaching and learning. It will facilitate the students to write or share everything freely. According to Matheson (2004), "A blog is an online journal which can be continuously updated by its users." By using a blog, students can share what do they feel in a non-formal way. They will not feel shy anymore to talk face to face as usual. Teachers also may not give the limitation about what they are going to write. We should give a chance to them to write as the way they are without space and constraints. The blog will help in the development of interpretive and critical thinking skills.

The aim of this study is to present how can blog integrate to teaching and learning process to enhance students' writing skill.

\section{LITERATURE REVIEW}

The term webblog is a contraction of two words: web and $\log$. Blogs are a tool for written communication and interaction. The term weblog refers to a personalized web page, kept by the author in reverse chronological diary form. As a "log on the web", it is kept first and foremost on the web, either on a static web page or via a database-backed website, enabled through blogging software. As a "log of the web", it easily refers to other Internet locations via hyperlinks (Simsek, 2009). Blogs are personal online journals which have recently become a collaborative technology and are regarded as a new way for people to express their thoughts in public (Nadzrah, 2009). This form of writing has become popular among Internet users. Most blog writers (bloggers) use this environment for selfexpression and empowerment, as writing in blogs helps people become more thoughtful and critical in their writing (Blood, 2002). Blogging software encourages frequent site updates with the content, or 'micro-content', as Alexander (2006) prefers to name it, is presented in reverse chronological order. Hence, the micro-contents or posts are mainly composed of the blogger's own opinions and thoughts, showing why they are referred to as 'online diaries' (Hourigan \& Murray, 2010). Moreover, blogs can successfully promote self-expression in a place where the L2 learner/blogger is developing deeply personalized content dealing with their language learning (Murray \& Harrigan, 2008). Being both potentially individualistic and collaborative, blogs can 
transcend linguistic barriers and may be used for language learning purposes, where bloggers become part of a discourse community in a complex multimodal setting and learning together in collaborative spaces where people negotiate and construct meaning and texts (Raith, 2009). Blogs can also be used to publish and exchange personal knowledge.

\section{DISCUSSION}

Blogging can offer opportunities for students to develop their communications skills through meaningful writing experiences. Such projects will not only motivate students to write but also motivate them to write well. Furthermore, studentblogging projects can be designed to address the Common Core State Standards for writing. However, many schools discovered that blogging can be used to develop children's English skills. Writing a blog about something meaningful, and that they are interested in, will inspire them to write more, and write better.

Ferdig and Trammell (2004) summarized the four main pedagogical benefits of blogging for students:

1. It assists students to become subject matter experts, as they scour and filter through web content searching for relevant information for their posts.
2. It increases students' interest in and ownership of learning.

3. It gives students legitimate chances to participate in a dialogue outside of the classroom and enculturates them into a community of practice.

4. It provides opportunities to share diverse perspectives.

On the other hand, Yunus, Tuan \& Sallehi (2011) found that there were some benefits of using blogs for students' writing skill in the classroom. According to them, blogs helped to gain free interaction so it was more non-formal, and there were no language barriers while writing in their blog. However, it wouldn't be appropriate to simply say some improper commands of language to lecturer but it could be used in blog anytime. Students could also use blogs for education not totally for socializing. Students can ask about assignments and talk about the lesson and etcetera.

Based on the study which was done by Kuimova \& Zvekov (2016), the use of blog could enhance the learning in a content area and can be a great help to maintain the desired level of students' education especially in writing. The study showed that $85 \%$ of the students in the experimental group expressed a positive attitude towards personal blogging. They noted that a blog provides opportunities to communicate on the internet, write for their peers (not just for 
their teacher), learn to form each other and get feedback not only from the teacher but also from their classmates. The students argued that blogging helped them to develop writing skills (55\%), build confidence in their writing $(45 \%)$, develop reading skills (35\%) and communicate useful information $(25 \%)$.

Moreover, Blackmore-Squires (2010) found that a blog could empower students to become analytical and critical writer, which in turn improve a student's self-confidence, while claiming that an online writing such as writing on blogs has many advantages to offer such as 1) encouraging feedback and representing both writing and reading activity;2) stimulating debate and critical analysis and encouraging articulation of ideas and opinions; 3) offering opportunities for collaborative learning; 4) providing an environment in which students can develop skills of persuasion and argumentation; 5) creating a more student-centered learning environment; and 6) offering informal language reading.

Suadah (2014) conducted a study about the use of blogging to enhance students' writing skill. She found that blogging was an exceptional technological platform that offered learners numerous advantages such as it encouraged them to write constructively, use English more frequently, and retained their motivation.
Using blogs has been presumed to be an effective way to encourage EFL students to write in English constructively (Bakar \& Ismail, 2009). This means, learning writing does not happen through knowledge transfer from teachers to students but it occurs because students actively improve their writing skills through attaining, generating, analyzing, manipulating and structuring the information. Constructive writing is important as it could lead EFL students to improve their writing through a series of the process which includes planning, writing, editing, posting and receiving feedback (Bakar \& Ismail, 2009). Learning through these steps is essential because of two reasons. First, it maintains information processing. Bruning, Schraw \& Norby (2011) point out that students could store massive information in their brain and retain it longer when they learn it step by step. Second, through these processes, students have opportunities to deeply understand information and write it in a sophisticated way before publishing it in blogs (Du \& Wagner, 2005). Then, there are some steps that could help us in using the blog for students writing skill:

\section{Choose a Purpose.}

Decide what you want students to write about, then work from there. Will you ask students to write reflective math or science journals, book reviews, or opinion 
pieces on current events? How can the blogging project support learning objectives in the discipline(s) you teach? Choose any focus that supports your students' learningbut make it specific and stick with it. This clear focus is crucial, especially your first time around, and especially with younger students.

\section{Decide on a Format and an Online}

\section{Platform}

You could opt for one class blog for all of your students' work. In this case, you'll be in charge of gathering student writing and posting it for them. This gives you complete control over the content. One pro: This strategy provides a built-in "quality-control" measure-nothing gets posted until you believe it's ready. And one con: You'll need to invest more time and effort as you gather and post each student's writing. Another option is for students to have their own individual blogs. In this case, each student has an individual username and password, and each is in charge of posting his or her own work.

\section{Prepare and Practice}

Structure your blogging project and prepare your students to understand the fact that others (classmates or, if the blog is public, anyone on the web) will read their work. This opportunity generates a great deal of excitement and motivation, but also requires a great deal of responsibility on students' parts. Remind them that blogs offer readers a chance to see their best workwork that has been drafted, edited, and revised. Leaving comments and responding to them are important parts of the blogging experience, so be sure to practice this kind of dialogue. Talk explicitly with students about the ramifications of negative blog posts and blog comments. Many teachers introduce online blogging with "paper blogging": Students write a practice blog post on a large piece of paper. Students then read each other's posts and practice commenting by writing responses to the post on sticky notes, which they then attach to the original piece of paper. Such activities can give your students practice with "publicly" displaying their work and commenting.

\section{Take it Public}

Once the student's blogs are up and running, Require them to read and comment on one another's work. And require individual bloggers to reply to every comment they receive. Receiving comments from readers outside of the classroom can be a powerful experience for students.

However, there are some considerations that teachers should take into account in order to help EFL students improve their writing through blogging 
(Richardson, 2009). Before integrating blogs into a writing lesson, the teachers should familiarize themselves with blogs, check the availability of the internet and train students in how to operate blogs. The goals of the lesson should also be specified unless the use of blogs will be meaningless. The teachers also need to control students' performance, encourage students to provide feedback and keep them safe. The safety is one crucial point that teachers need to consider because students could possibly interact with many general bloggers outside of class. Therefore, it is very important that teachers give clear instruction about how to use the blogs in the lesson. They should also give clear guidelines about how often students should post, how long the posts should be, how many hyperlinks should be included in each post and what is inappropriate to write (Ferdig \& Trammell, 2004 as cited in Richardson, 2009). In cases where students are assigned to conduct research and then post their findings in the blog, they should be required to link to their sources when possible, to avoid the temptation of plagiarism.

\section{CONCLUSION}

Writing is one of the basic skills that should be had by the students as the result of the learning process. Nowadays, people are expected to be able to read and write. Those two skills are considered an important role in all aspects of life. In order to help our students have a good skill in writing, the use of technology is chosen to be integrated into the learning process. Blogging is one of the activities that can be used to motivate the students to write actively and constructively. From the discussion, we can conclude that teachers can use blogs to help students write constructively, promote student's autonomy and enhance their motivation. Blogging could be a solution for writing problems that many foreign language learners are struggling with. EFL learners could improve their fluency by frequently post their writing on blogs. However, the accuracy element cannot be simply obtained through blogging. Hence, EFL learners need extra self-study time to acquire this skill. Moreover, teachers who aim to integrate blogging in their teaching need to be aware of their students' need, teaching context and learning goals in order to get the most benefits of using blogs in their teaching. Blogging seems to be very beneficial to help the students improve their writing skills as long as teachers use it purposefully in the lesson.

\section{REFERENCES}

Alexander, B. (2006). A new wave of innovation for teaching and learning. EDUCAUSE Review, pp. 33-34. 
Amiri, E. (2012). A study of the application of digital technologies in teaching and learning English language and literature. International Journal of Scientific Technology Research. 1 (5).

Bakar, N., \& Ismail, K. (2009). Using blogs to encourage ESL students to write constructively in English. AJTLHE, 1 (1), 45- 57.

Blackmore, S. S. (2010). An investigation into the use of $s$ blog as a tool to improve writing in the language classroom. Unpublished MA dissertation. UK: University of Manchester,

Blood, R. (2002). Weblogs: A history and perspective, In Editors of Perseus Publishing (Eds).

Bruning, R.H., Schraw, G.J., Norby, M.M. (2011). Cognitive psychology and instruction (5th ed.). Boston: Pearson.

Dunlosky, J., Katherine, R., Elizabeth, J., Mitchel, N \& Daniel, T. (2013). Improving students' learning with effective learning techniques: Promising directions from cognitive \& education psychology. The University of Virginia.

Harmer, J. (2001). The practice of English Language Teaching 3rd Edition. New York: Longmann.

Hourigan, T., \& Murray, L. Using blogs to help language students to develop reflective learning strategies: Towards a pedagogical framework. Australasian Journal of Educational Technology. 26 (2).

Kuimova, M. V., \& Zvekov, O. D. (2016). Blogs as a means to enhance writing skills in EFL classes. IJET. 11 (4).

Matheson, D. (2004). Weblogs and the epistemology of the news: some trends in online journalism. New Media and Society, 6 443-468.

Murray, L., \& Hourigan, T. (2008). Blogs for specific purposes: Expressivist or Socio-cognitivist Approach? ReCALL, 20 (1).

Nadzrah, A.B. (2009). E-learning environment: Blogging as a platform for language learning. The European Journal of Social Science. 9, 594-604.

Raith, T. (2009). The use of Weblogs in language education. In M. Thomas (Ed), Handbook of Research on Web 2.0 and Second Language Learning IGI Global, 224-291.

Richardson, W. (2008). Blogging: Digital media and society series. Cambridge: Polity Press.

Saleh, A. (2015). Improving Students' ability in writing narrative text through accelerated Approach. Unpublished thesis, English Applied Linguistics Study Program, State University of North Sumatera, Indonesia. 
Santoso, D. (2016). Improving the students' spiritual intelligence in English writing through whole brain learning. English Language Teaching, 9(4).

Simsek, O. (2009). The effect of weblog integrated writing instruction on primary school students writing performance. International Journal of Instruction. 2 (2).

Suadah, L. (2014). Enhancing EFL learners writing skills through blogging. English. 2 (1), 20 -29.

Trammell, K.D. \& Ferdig, R.E. (2004). Pedagogical implications of classroom blogging. Academic Exchange Quarterly, 8(4), 60-64.

Yunus, M., Tuan, J.L.K., 7 \& Salehi, H. (2011). Using Blogs to promote writing skills in ESL Classroom. Recent Advances in Educational Technologies. 